\title{
PVA Nanofibers Including Biopolymer-grafted Copolymer for Potential Biomedical Applications
}

\author{
Potansiyel Biyomedikal Uygulamalar için Biyopolimer- \\ Yamalanmış Kopolimer İçeren PVA Nanofiberler
}

\author{
Research Article
}

Murat Şimşek

Faculty of Engineering, Department of Biomedical Engineering, İönü University, Malatya, Turkey.

\section{A B S TR AC T}

$\mathrm{M}$ ultifunctional nanofibers were fabricated by electrospinning of polyvinyl alcohol/octadecylamine montmorillonite layered silicate nanocomposite as a matrix polymer and amphiphilic copolymer-g-biopolymer (polylactic acid, PLA) as a biocompatible partner polymer. Crystal structure of the nanofibers significantly changed due to in situ phase separation processing via different chemical and physical interfacial interactions. Relative high thermal stability, high first melting and low crystallinity were observed for the matrix/polymer nanofibers. Nanofibers exhibit low cytotoxicity and necrotic effect for MC3T3-E1 preosteoblast cells.

\section{Key Words}

PVA, copolymer-g-PLA, organoclay, electrospinning.

\section{öz}

ok fonksiyonlu nanofiberler matris polimer olarak polivinil alkol/oktadesilamin montmorillonit tabakalı silikat nanokompozitin ve biyouyumlu partner polimer olarak amfifilik kopolimer-g-biyopolimer'in (polilaktik asit, PLA) elektroeğrilmesi ile üretilmişlerdir. Nanofiberlerin kristal yapısı farklı kimyasal ve fiziksel arayüzey etkileşimler yoluyla ortaya çıkan in situ faz ayrımı prosesi sebebiyle önemli seviyede gelişmiştir. Nanofiberler MC3T3-E1 preosteoblast hücreleri varlığında düşük seviyede sitotoksik ve nekrotik etki sergilemişlerdir.

\section{Anahtar Kelimeler}

PVA, kopolimer-g-PLA, organokil, elektroeğirme.

Article History: Received: Sep 29, 2017; Revised: Jan 23, 2018; Accepted: Sep 3, 2018; Available Online: Oct 4, 2018

DOI: 10.15671/HJBC.2018.245

Correspondence to: M. Şimşek, Faculty of Engineering, Dept. of Biomedical Engineering, İnönü University, Malatya, Turkey. 


\section{INTRODUCTION}

Dolymer nanofibers from various polymers such as engineering plastics, biopolymers, conducting polymers, block and graft copolymers and matrix-partner polymer blend systems have attracted a great deal of attention due to their unique properties, such as high surface area-to-volume ratio, low basis weight, excellent structural mechanical properties, high axial strength combined with extreme flexibility, high functionality and high porosity [1-4] Electrospinning is a simple, low cost, and effective technology to prepare nanofibers from these polymers for various applications $[5,6]$.

Electrospun polymeric nanofibers incorporated with inorganic nanoparticles inside have great interest for their potential applications in biomedical and photonics. Larsen et al. firstly combined electrospinning with sol-gel methods to design vesicles and nanofibers made from inorganic oxides and hybrid (organic/inorganic) materials [7]. A wide range of potential nanosized fillers have been used for the preparation of high efficient nanocomposites. Among them, clays and layered silicates have been considerably investigated since they are environmentally friendly, naturally occurring, readily available, and low cost. One of the most extensively used clay is montmorillonite (MMT) and it has been employed in many polymer nanocomposite systems as filler [8-10]. However, in most cases, it needs to be organically modified to produce well-organized nanocomposites [10]. Octadecylammonium derivatives are typical used for preparing organomodified MMT [11]. The composite material based on poly(butylene succinate), poly(butylene adipate-co-terephthalate) and organo-modified montmorillonite (OMMT) were prepared by melt blending technique and characterized [12]. Results showed that tensile strength, thermal stability, and the morphology of the blends improved with presence of OMMT.

Poly(vinyl alcohol) (PVA) is a hydrophilic and semi-crystalline polymer that has received great attention due to its excellent biocompatibility, non-toxicity, and good water permeability. These properties have led to the use of PVA in a number of applications in medical, pharmaceutical, food, cosmetic and packaging industries [13-17]. As a matrix polymer, PVA has also excellent filmand fiber-forming, emulsifying, surfactant and adhesive properties and utilized to fabricate unique nanofiber compositions [18-20]. Development of PVA-clay nanocomposites has attracted many researches attention in order to improve its mechanical, thermal, and gas barrier properties. Zhuo et al. prepared PVA/hydrotalcite composite nanofibers by electrospinning [13]. In another study, PVA/MMT composite fibers were investigated by Lee et al. [21]. Strawhecker and Manias prepared the PVA/clay nanocomposites by casting the water suspension of PVA and MMT [22].

The polymeric biomaterials and their synthetic structural analogs as well as biopolymer nanocomposites with specific surface activity as potential bone substitute materials were utilized to control cellular and physiologic responses [2325]. Meredith and Amis reported the effect of the chemistry, microstructures, and roughness of polymer (poly ( $D, L$-lactide) and poly( caprolactone)) blends on MCT3T3-E1 osteoblast cell function [26]. In a study osteoblasts' response was investigated to a biodegradable porous composite of poly (lactide-co-glycolide) and hydroxyapatite in order to quantitatively assess the matrix's ability to support living cell adhesion [27].

Recent developments in the fabrication of bioactive functional polymer systems, polymer capsulated nanoparticles, biopolymers, and synthetic polymers functionalized with bioactive groups have indicated that these systems can be successfully utilized in many areas, especially in tissue and bone engineering. In this work, we developed a new approach for the fabrication of polymer nanocomposites and nanofibers reinforced with reactive organoclay and biocompatible partner polymer by electrospinning method. Another aspect of this work was to evaluate effects of structural factors and incorporated reactive organoclay on the in situ processing, physical and chemical interfacial interactions in the formation of nanostructures, as well as influence of partner polymer on osteoblast cells. 


\section{MATERIALS and METHODS Materials}

PVA (89 \% hydrolyzed, average $\mathrm{Mw}=31.000-$ $51.000 \mathrm{~g} / \mathrm{mol})$, L-Lactic acid $(98 \%$ analytical standard, density $1.209 \mathrm{~g} / \mathrm{cm}^{3}$, refraction index 1.427) were purchased from Sigma-Aldrich. Maleic anhydride (Fluka) monomer was purified by recrystallization from anhydrous benzene solution and sublimated under vacuum before its use. Analytical grade 1-octadecene olefin monomer (Aldrich) was used without purification. Octadecyl amine-montmorillonite (ODA-MMT, Nanomer 1.30E, Nanocor Co.) was purchased from Aldrich having the following average parameters: content of ODA surfactant-intercalant $25-30 \%$, particle size $8-10 \mu \mathrm{m}$, bulk density $0.41 \mathrm{~g} / \mathrm{cm} 3$ caption exchange capacity (CEC) $95 \mathrm{mEq}$ and crystallinity 55.0 \% (by XRD). Deionized pure water was used as a medium. Dimethylformamide (DMF) as a solvent for partner polymer, dimethylsulfoxide (DMSO) as a water absorbent and other solvents and reagents were analytical grade and used without purification. MC3T3-E1 preosteoblast cells were obtained from ATCC. Cell culture flasks and other plastic material were purchased from Corning. Dulbecco Modified Eagle's Medium with L-glutamine, fetal calf serum, Trypsin-EDTA, Hoechst 33342 and propidium iodide were purchased from Serva.

\section{Synthetic Procedure}

PVA (96.5 wt\%)/ODA-MMT (3.5 wt\%) layered silicate nanocomposite as a matrix polymer was synthesized by intercalation of PVA between layers of ODA-MMT organoclay in pure water solution by intensive mixing at $80^{\circ} \mathrm{C}$ for $3 \mathrm{~h}$ up to formation of homogeneous viscose product.

The production of poly(MA-alt-1-octadecene)$\mathrm{g}$-PLA (molecular mass $35.960 \mathrm{~m} / \mathrm{z}$ ) as a partner was realized according to our previous study [28]. Briefly, it was synthesized by graft copolymerization of L-lactic acid (LA) onto amphiphilic alternating copolymer of maleic anhydride with 1-octadecene (as a first preventer) via esterification-grafting of anhydride units with LA. The following graft copolymerization was performed under vacuum in the presence of DMSO as a water absorbent and isopropanol as a second preventer at $80^{\circ} \mathrm{C}$ using a specially constructed vacuum reactor with Dean-Stark unit. Graft copolymer was isolated from reaction mixture by twice precipitation by ethanol, and then, dried under vacuum at $60^{\circ} \mathrm{C}$ for $6 \mathrm{~h}$.

\section{Fabrication of Nanofibers by Electrospinning}

Fabrication of nanocomposite fibers (NCF) from blends of matrix polymer (PVA/ODA-MMT)/ partner polymer (copolymer-g-PLA) with ratios of 10/0 (NCF-10/0), 9/1 (NCF-9/1), 8/2 (NCF-8/2), and $0 / 10(\mathrm{NCF}-\mathrm{O} / 10)(\mathrm{v} / \mathrm{v})$ were realized by using following electrospinning parameters: a syringe pump (NE 300, New Era Pump Systems) with a gauge needle was fixed vertically with the flow rate of $1.5 \mathrm{~mL} / \mathrm{h}$; a distance of $15 \mathrm{~cm}$ was set between needle tip-to-collecting aluminum foil; and high voltage (Gamma High Voltage Research) of $23 \mathrm{kV}$ was applied between the capillary and the collector. Matrix/partner polymer concentrations were 10 wt $\%$ for both solutions. Distilled water was the solvent for the matrix polymer, whereas DMF was used for the partner polymer.

\section{Characterization}

The surface morphology of nanofibers was examined by a Scanning Electron Microscope (SEM). Fiber diameters were calculated by ImageJ software (NIH, Bethesda, MD) by taking the average of at least 100 measurements from SEM images.

Fourier Transform Infrared(FTIR) spectra were recorded on a Thermo-Nicolet 6700 spectrometer in the range of $4000-500 \mathrm{~cm}^{-1}$ with a resolution of $4 \mathrm{~cm}^{-1}$. X-ray powder diffraction (XRD) patterns were obtained with a X-ray diffractometer equipped with a CuK tube and $\mathrm{Ni}$ filter $(\lambda=$ $1.5406 \AA$ A). XRD diffractograms were measured at 2 , in the range $1-50^{\circ}$. The Bragg equation was used to calculate the interlayer spacing $(d): n=$ $2 d \sin$, where $\mathrm{n}$ is the order of reflection, and is the angle of reflection. Average crystallite size of nanocrystalline domains in matrix polymer/ partner polymer nanofibers was determined by using the following Scherrer equation: $\tau_{\text {sh }}$ $=K / \cos$, where, is mean crystallite size of the ordered nanocrystalline domains; $\mathrm{K}$ is dimensional shape factor with a typical value of about 0.89, but varies with the actual shape of crystallite; is the X-ray wavelength (1.5406 
$\AA$ of $\mathrm{Cu} \mathrm{K}$ radiation); is the line broadening at half the maximum intensity (FWHM) which is also sometimes donated as $\Delta(2) ; \quad$ is the Bragg angle.

Thermogravimetric (TGA) and differential scanning calorimetric (DSC) analyses were performed using EXTRAR600 TG-DTA6300 and Diamond DSC Perkin Elmer Thermal Analyzers by using a linear heating rate of $10^{\circ} \mathrm{C} / \mathrm{min}$ under nitrogen flow. Samples were measured in a sealed alumina pan with a mass of about $10 \mathrm{mg}$.

\section{Cytotoxicity and Necrotic Effect}

WST-1 test was used to evaluate cytotoxicity of nanofibers against human MC3T3-E1 osteoblast cells. In this procedure, the tetrazolium salts are cleaved to formazan by succinate tetrazolium reductase enzyme. An increase in the number of viable cells results in an increase in the overall activity of mitochondrial dehydrogenases in the samples. Quantification of the formazan dye produced by metabolically active cells is determined by Elisa-Reader. MC3T3-E1 cells were cultured into 96 -well plate $\left(5 \times 10^{3}\right.$ cells/well) and incubated for $24 \mathrm{~h}$ at $37^{\circ} \mathrm{C}$. Different amounts $(25-200 \mu \mathrm{g} / \mathrm{mL})$ of PVA/ODA-MMT NCF-10/0 and matrix polymer/partner polymer nanofibers (NCF-8/2) were added in the incubation medium and the incubation was sustained additionally for $24 \mathrm{~h}$. Then, $15 \mu \mathrm{L}$ of WST-1 solution was added to each well and the culturing time was set to $4 \mathrm{~h}$. Thereafter, the absorbance at $440 \mathrm{~nm}$ was measured by an ELISA plate reader. Wells not containing fiber mats were used as a control group.

Double staining with Hoechst dye 3342 (2 $\mu \mathrm{g} / \mathrm{mL}^{-1}$ ) and propidium iodide (PI) was used to quantify the number of necrotic cells $\left(10 \times 10^{3}\right.$ cells/well) seeded into 24 - well plates with DMEM medium. After treating with different concentrations $(25-200 \mu \mathrm{g} / \mathrm{mL})$ of NCF-10/0 and $\mathrm{NCF}-8 / 2$ for $48 \mathrm{~h}$, attached and detached cells were harvested. After washing with PBS, cells were incubated with Hoechst dye $3342(2 \mu \mathrm{g} /$ $\left.\mathrm{mL}^{-1}\right), \mathrm{PI}\left(1 \mu \mathrm{g} / \mathrm{mL}^{-1}\right)$ and DNAse free-RNAse (100 $\left.\mu \mathrm{g} / \mathrm{mL}^{-1}\right)$ for $15 \mathrm{~min}$ at room temperature. Then, 10-50 $\mu \mathrm{L}$ of cell suspension was smeared on a glass slide and cover slipped for examination under a fluorescence microscope (Leica, DMI
6000). In the double staining method, the nuclei of normal cells are stained light blue by Hoechst whereas necrotic cells are stained red by PI. As necrotic cells lack of plasma membrane integrity, $\mathrm{PI}$ dye can cross the cell membrane. The number of necrotic cells in 10 random microscopic fields were counted. The number of apoptotic and necrotic cells were determined with DAPI and FITC filters of a Fluorescence Inverted Microscope (Leica,Germany). Data was expressed as the ratio of necrotic cells to normal cells. Each group was triplicated.

\section{RESULTS AND DISCUSSION Synthesis and Characterization of Nanofibers}

The surface morphologies of nanofibers were investigated by SEM. SEM images of partner polymer fibers showed beaded morphology (Figure 1a). In contrast, matrix/partner polymer nanofiber mats (10/0, 9/1 and 8/2, v/v) exhibited smooth and regular morphology (Figures 1b, c-e, and $f-h)$. Micro-beaded morphology of fibers from partner polymer fully disappeared when it was blended with matrix polymer. Matrix polymer/ partner polymer nanofibers with ratios of $10 / 0,9 / 1$ and $8 / 2(\mathrm{v} / \mathrm{v})$ had diameters of $323 \pm 62 \mathrm{~nm}, 312 \pm 56$ $\mathrm{nm}$, and $290 \pm 40 \mathrm{~nm}$, respectively. An increase in partner polymer ratio had an effect in favor of obtaining thinner and more uniform nanofibers. SEM results also indicated that the concentration of partner polymer was an important parameter to optimize electrospinning conditions and control in situ reactive fiber formation processing. On the other hand, the loading reactive organoclay and structural factors from functional matrix/ partner polymers influenced the surface morphology of nanofibers due to different types and degrees of in situ physical and chemical interfacial interactions during the formation of thermodynamically stable fibrous morphology with higher surface area. Among NCFs NCF-8/2 was used for further characterization studies due to its better morphology and uniformity.

Figure 2a shows FTIR spectrum of NCF-8/2. Pristine PVA has characteristic $\mathrm{OH}$ peak at 3304 $\mathrm{cm}^{-1}$ [29]. However, the area and intensity of this band in the spectra of matrix polymer/partner polymer nanofibers essentially increased and 


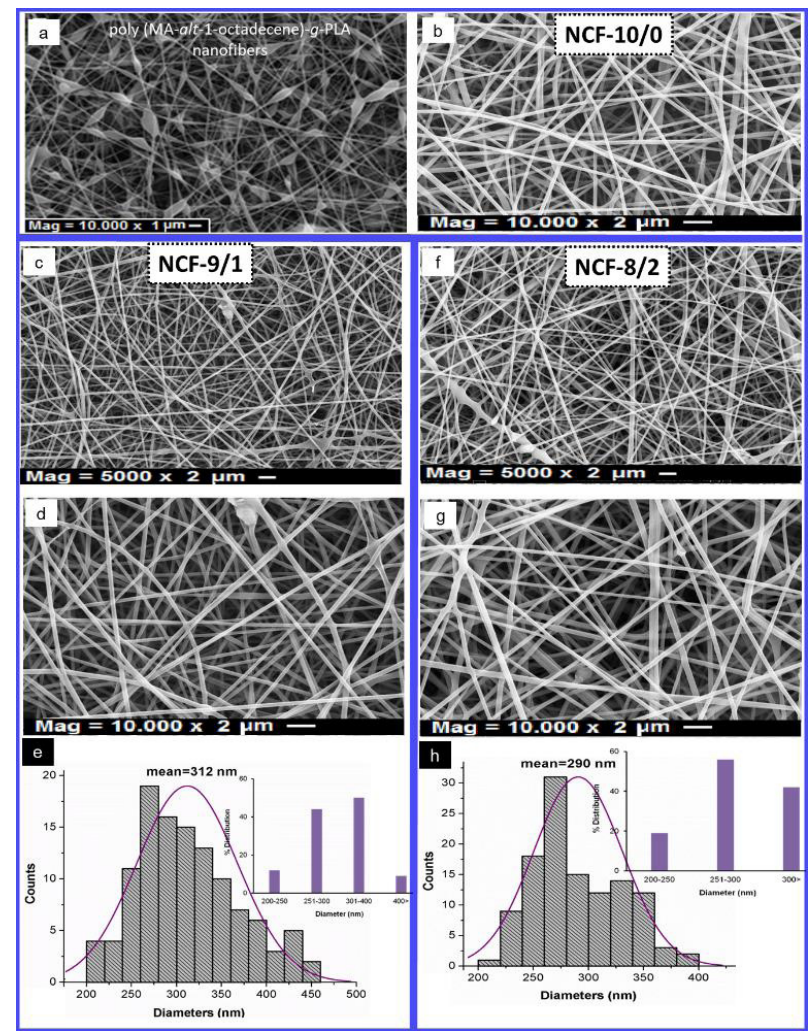

Figure 1. SEM images of (a) partner polymer fibers, b) NCF-10/0 (c-e) NCF-9/1, and (f-h) NCF-8/2 with their diameter distribution.

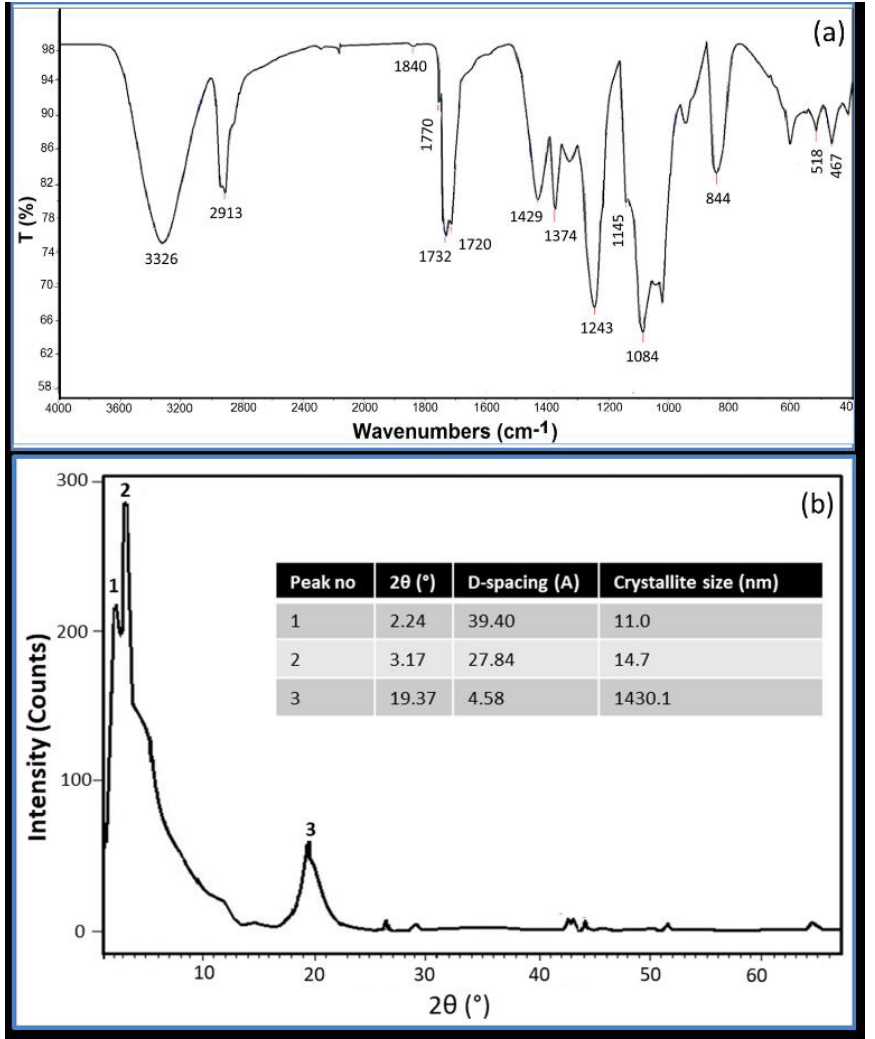

Figure 2. a) FTIR spectra and b) XRD patterns and reflection parameters of NCF-8/2. 
shifted to higher region (from 3304 to $3326 \mathrm{~cm}$ 1) due to formation of the additional complexes through the interactions carboxyl-OH and amine$\mathrm{OH}$ groups. The absorption band around $2913 \mathrm{~cm}^{-1}$ was related to $\mathrm{C}-\mathrm{H}$ stretching from $\mathrm{CH}$ and $\mathrm{CH}_{2}$ groups of backbone chain of PVA and octadecyl amine surfactant from organoclay, respectively. These bands were confirmed with presence of the bending vibrations around $1429-1374 \mathrm{~cm}^{-1}$ from $\mathrm{CH}_{2}$ groups. Bands at 1732, 1720 and 1050 (weak) $\mathrm{cm}^{-1}$ were related to ester $\mathrm{C}=\mathrm{O}$ and $\mathrm{C} \uparrow \mathrm{O}$ groups from vinyl acetate and maleate units of partially hydrolyzed PVA, monoesterificated graft copolymer and its side-chain PLA fragment, respectively. The characteristic two stretching bands at 1770 and $1840 \mathrm{~cm}^{-1}$ were associated with $\mathrm{C}=\mathrm{O}$ groups of maleic anhydride/maleate units of partner polymer [28]. The $\mathrm{C}-\mathrm{O}$ band from $\mathrm{C}$ $\mathrm{OH}$ groups appeared at 1243 and $844 \mathrm{~cm}^{-1}$. FTIR spectrum also show the characteristic broad band at 1145 and $1084 \mathrm{~cm}^{-1}$, which were associated with $\mathrm{Si}-\mathrm{O}$ and $\mathrm{Si}-\mathrm{O}-\mathrm{Si}$ stretching from dispersed ODA-MMT layers in matrix polymer. Bands at 467 and $518 \mathrm{~cm}^{-1}$ were related to the $\mathrm{Si}-\mathrm{O}$ bending and $\mathrm{Al}-\mathrm{O}$ stretching, respectively.

The physical structures of nanofibers were investigated by XRD analysis (Figure $2 b$ ). Pristine partner polymer had predominantly amorphous structure with weak crystalline peaks at 2 around $19-26^{\circ}$ due to branched PLA fragment [28]. PVA has intense characteristic peak around 19-20 ${ }^{\circ}$ [28]. When partner polymer was added to matrix polymer the peak intensity decreased in favoring lowering the crystallinity. The nanofiber films showed various diffraction peaks from crystals of layered silicate fragments, partner polymer chains and octadecyl amine surfactantintercalant. Diffraction parameters of pristine ODA-MMT [31] significantly changed when it was incorporated with the partner polymer. Characteristic peak belonging to the organoclay $\left(4.45^{\circ}\right)$ shifted to $2.24^{\circ}$ and $3.17^{\circ} 2$. In addition, $d_{\text {(002) }}$ spacing (22.29 $\AA$ ) increased to $39.40 \AA$ and $27.84 \AA$. Thus, (PVA/ODA-MMT)/copolymer$g$-PLA fiber nanocomposites predominantly exhibited an intercalated nanostructure. In conclusion, crystal structure of the matrix/partner polymer nanofibers significantly changed due to in situ phase separation processing via different chemical and physical interfacial interactions, and it was observed an improvement structural compatibility of applied multifunctional matrix and partner polymers in colloidal and solid states.

\section{Thermal Behaviors of Nanofibers}

Figure 3 shows TGA-DSC curves of NCF-8/2. Thermal degradation properties of matrix/partner

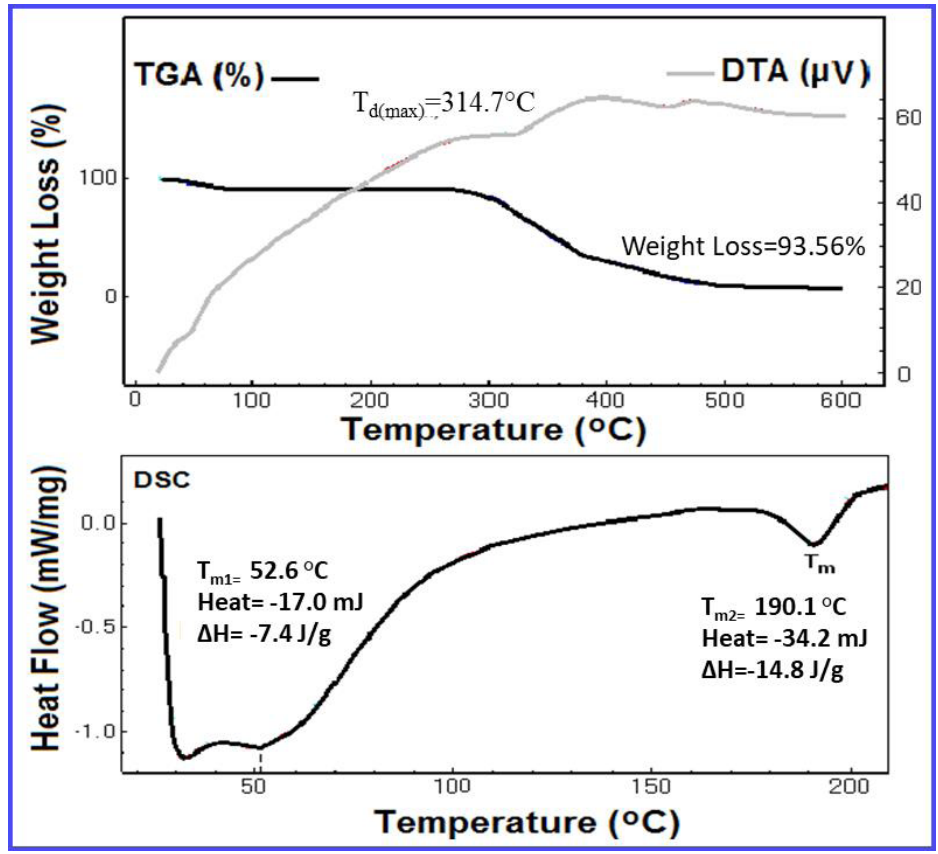

Figure 3. TGA-DTA and DSC thermal behaviors of NCF-8/2. 
Table 1. Cytotoxic and necrotic effects of NCF-10/0 and NCF-8/2 against MC3T3-E1 osteoblast cells.

\begin{tabular}{lcccc}
\hline $\begin{array}{l}\text { Concentration of } \\
\text { nanofibers }\end{array}$ & \multicolumn{2}{c}{ NCF-10/0 } & \multicolumn{2}{c}{ NCF-8/2 } \\
\hline$(\mu \mathrm{g} / \mathrm{mL})$ & cell viability $(\%)$ & necrotic cells $(\%)$ & cell viability (\%) & necrotic cells (\%) \\
\hline 0 & $100 \pm 0.5$ & $2 \pm 1$ & $100 \pm 0.5$ & $2 \pm 1$ \\
\hline 25 & $99 \pm 1.7$ & $3 \pm 1$ & $99 \pm 0.8$ & $1 \pm 1$ \\
\hline 50 & $94 \pm 2.1$ & $5 \pm 1$ & $98 \pm 0.7$ & $2 \pm 1$ \\
\hline 100 & $91 \pm 0.8$ & $10 \pm 1$ & $97 \pm 0.5$ & $3 \pm 1$ \\
\hline 200 & $87 \pm 0.5$ & $14 \pm 1$ & $95 \pm 2.3$ & $4 \pm 1$ \\
\hline
\end{tabular}

polymer nanofibers from TGA and DTA analysis are also illustrated in Figure 3. Agreeing with these results, NCF-8/2 exhibited two step chain degradation with total weight loss $93.56 \%$. The broad exothermic peaks around $300-350^{\circ} \mathrm{C}$ in the DTA curves can be attributed to the degradation processing the side chain through loss of hydroxyl groups and main chains of copolymer reinforced with organoclay. Relative high thermal stability was observed for NCF-8/2 $\left(T_{\mathrm{d}(\max )}=314.7^{\circ} \mathrm{C}\right)$ as compared with those for pristine powder PVA ( $T_{d}$ $\left.(\max )=298^{\circ} \mathrm{C}\right)[29]$ and PVA/ODA-MMT nanofibers $\left(T_{\mathrm{d}(\max )}=295^{\circ} \mathrm{C}\right)$ [29]. The first transition observed in DSC curve can be attributed to thermal effects due to melt-transition $\left(T_{m 1}\right)$ branched PLA chains and second endothermic peaks due to melting transition $\left(T_{\mathrm{m} 2}\right)$ of nanostructured fibers. The broad exothermic peaks around $75-150^{\circ} \mathrm{C}$ can be attributed to the chemical interactions of functional groups from copolymer and organoclay at applied isothermal conditions. The comparative analysis of these polymer systems indicated that nanofibers from matrix/partner polymer system exhibited relative high first melting $T_{\mathrm{m} 1}$ value $\left(52.6^{\circ} \mathrm{C}\right)$ than those for pristine PVA $\left(39.59^{\circ} \mathrm{C}\right)$ [29] and PVA/ODA-MMT nanofiber $\left(23.08^{\circ} \mathrm{C}\right)$ [29]. All these polymer systems showed approximately the same $T_{\mathrm{m}}$ values $\left(190^{\circ} \mathrm{C}\right)$ with the different heat and enthalpy $(\Delta \mathrm{H})$ parameters. The enthalpy $(\Delta \mathrm{H})$ strongly depended on the composition and structural factors of nanofibers and changed from $27.45 \mathrm{~J} / \mathrm{g}$ (pristine PVA) [29] to 25.34 (NCF10/0) [29] and $14.9 \mathrm{~J} / \mathrm{g}$ (NCF-8/2). Crystallinity of NCF-8/2 were calculated using $\Delta H^{\circ}=67.38$ $\mathrm{J} / \mathrm{g}$ for $100 \%$ melting of PVA. The value of crystallinity obtained from DSC curve of NCF-8/2 $\left(\chi_{c}=10.75 \%\right)$ was lower than those for pristine PVA $\left(\chi_{c}=40.70 \%\right)$ [29] and NCF-10/0 ( $\left.\chi_{c}=33.2 \%\right)$ [29]. This observed relative low value of matrix/ partner polymer nanofibers can be explained by transformation of nanofibers to the colloidal state with amorphous structures via electrospinning of matrix polymer/partner polymer composites.

\section{Cytotoxic and Necrotic Effect of Nanofibers}

In order to determine if the fibrous mats released toxic products or not, cytotoxicity test was carried out. Cytotoxicity of NCF-10/0 and at various concentrations $(25-200 \mu \mathrm{g} / \mathrm{mL})$ were determined by testing the viabilities of MC3T3-E1 cells. WST-1 method was used for evaluating the cell viabilities and testing results are summarized in Table 1. As a control, no fiber-added cell cultures were used. Although the cell viability decreased with increasing fiber ratio in the culture medium, tolerable amounts of toxicity were determined for NCF-10/0 fibers at all used concentrations. However, NCF-8/2 had lower degree of toxicity than NCF-10/0 fibers. This can be attributed the presence of biocompatible partner polymer in NCF-8/2. The images of necrotic cells are illustrated in Figure 4 and necrotic index values are summarized in Table 1. The necrotic effects appeared to change in parallel with the toxicity results. PLA side-chain biofragments in the nanofiber structure of NFC-2, which did not exist in organoclay modified PVA fibers, improved its biocompatibility for the osteoblast cells. This can be concluded a role of impact generator for physical and chemical stimulation of osteoblast cells. 


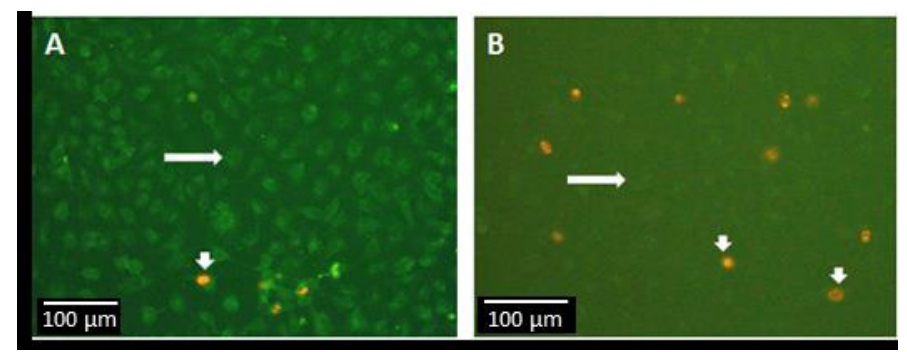

Figure 4. Inverted fluorescent light microscopy image of double staining osteoblast cells. A) Control group image, B) Sample including group (long arrow and short arrow show non-necrotic cell nuclei and necrotic cell nuclei, respectively).

\section{Conclusion}

This work presents novel multifunctional polymeric nanofibers fabricated from solution blends of the PVA/ODA-MMT and amphiphilic reactive copolymer-g-PLA as matrix/partner polymers by electrospinning for potential bone and tissue engineering applications. Matrix/partner polymer nanofibers exhibited semi-crystalline structures due to intermolecular hydrogen bonding and absorbed water molecules. The comparative analysis of surface morphologies of the fibers revealed the formation of nanofibrous structures with cross-section morphology and fine diameter distribution fabricated from matrix/partner polymer solutions blends. Incorporation of the partner polymer to fiber composition significantly increased reactivity of fiber surfaces and their biocompatibility due to reactive anhydride units and grafted PLA biopolymer. The structural factors played an important role in situ interfacial interactions and phase separation processing. Cytotoxic and necrotic effects of polymer nanofibers against MC3T3-E1 cells depended on the structure, composition and surface morphology of nanofibers. NCF-2 having PLA sidechain biofragments improved biocompatibility of fibers for the cells. It was proposed that the structural factors, especially hydrogen bonding in the chosen reactive organoclay, functional matrix and partner polymers played an important role in phase separation processing, in situ interfacial interactions and in the formation of selfassembled thermodynamically stable nanofiber structures as effective platforms for future incorporation of various biopolymer systems.

\section{References}

1. D.H. Reneker, I. Chun, Nanometre diameter fibres of polymer, produced by electrospinning, Nanotechnology, 7 (1996) 216-223.

2. D. Li, Y. Wang, Y. Xia, Electrospinning of polymeric and ceramic nanofibers as uniaxially aligned arrays, Nano Lett., 3 (2003) 1167-1171.

3. K.H. Hong, Preparation and properties of electrospun poly(vinyl alcohol)/silver fiber web as wound dressings, Poly. Eng. Sci., 47 (2007) 43-49.

4. B. Gupta, R. Agarwal, M.S. Alam, Textile-based smart wound dressings, Indian J. Fibre Text., 35 (2010) 174187.

5. A. Arslan, M. Şimşek, S.D. Aldemir, N.M. Kazaroğlu, M. Gümüşderelioğlu, Honey-based PET or PET/ chitosan fibrous wound dressings: effect of honey on electrospinning process, J. Biomat. Sci.-Polym. E., 25 (2014) 999-1012.

6. S. Çakmak, A.S. Çakmak, M. Gümüşderelioglu, RGD-bearing peptide-amphiphile-hydroxyapatite nanocomposite bone scaffold: an in vitro study, Biomed. Mater., 8 (2013) 04501.

7. G. Larsen, R. Velarde-Ortiz, K. Minchow, A. Barrero, I.G. Loscertales, A method for making inorganic and hybrid (organic/inorganic) fibers and vesicles with diameter in the submicrometric and micrometric range via sol-gel chemistry and electrically forced liquid jets, J. Am. Chem. Soc, 125 (2003) 1154-1155.

8. E. Manias, A. Touny, L. Wu, K. Strawhecker, B. Lu, T.C. Chung, Polypropylene/Montmorillonite Nanocomposites. Review of the synthetic routes and materials properties. Chem Mater. 13 (2001) 35163523.

9. K.-U. Jeong, H.D. Chae, Lim C. II, H.K. Lee, J.-H. Ahn, C. Nah, Fabrication and characterization of electrolyte membranes based on organoclay/tripropyleneglycol diacrylate/poly(vinylidene fluoride) electrospun nanofiber composites, Polym. Int., 59 (2010) 249-255.

10. S.M. Nabirqudri, A.S. Roy, and M.V.N. Ambika Prasad, Electrical and mechanical properties of free-standing PMMA-MMT clay composites, J. Mater. Res., 29 (2014) 2957-2964.

11. D. Merinska, Z. Malac, M. Pospisil, Z. Weiss, M. Chmielova, P. Capkova,J. Simonik, Polymer/clay nanocomposites based on MMT/ODA intercalates, Compos. Interface., 9 (2002) 529-540. 
12. B.W. Chieng, N.A. Ibrahim, W.M.Z. Wan Yunus, Effect of organo-modified montmorillonite on poly(butylenesuccinate)/poly(butylene adipate-coterephthalate) nanocomposites, Express Polym. Lett. 4 (2010) 404-414.

13. Q. Zhuo, G. Xu, J. Wang, C. Qin, L. Dai, Poly(vinyl alcohol)/hydrotalcite composite nanofibre: preparation and characterization, Iran. Polym. J., 20 (2011) 357-365.

14. J.H. Juang, S. Bonner-Weir, Y. Ogawa, J.P. Vacanti, G.C. Weir, Outcome of subcutaneous islet transplantation improved by polymer device, Transplantation, 61 (1996) 1557-1561.

15. Y. Deng, X. Zhang, Y. Zhao, S. Liang, A. Xu, X. Gao, F. Deng, J. Fang, S. Wei, Peptide-decorated polyvinyl alcohol/hyaluronan nanofibers for human induced pluripotent stem cell culture, Carbohydr. Polym., 101 (2014) 36-39.

16. U.M. Subramanian, S.V. Kumar, N. Nagiah, U. T. Sivagnanam, Fabrication of polyvinyl alcoholpolyvinylpyrrolidone blend scaffolds via electrospinning for tissue engineering applications. Int. J Polym. Mater. Po., 63 (2014) 476-485.

17. M. Kokabi, M. Sirousazar, Z.M. Hassan, PVA-clay nanocomposite hydrogels for wound dressing, Eur. Polym. J., 43 (2007) 773-781.

18. T. Galya, V. Sedlarik, I. Ku itka, R. Novotný, J. Sedla íková, P. Sáha, Antibacterial poly(vinyl alcohol) film containing silver nanoparticles: Preparation and characterization, J. Appl. Polym. Sci., 110 (2008) 3178-3185.

19. M. Jannesari, J. Varshosaz, M. Morshed, M. Zamani, Composite poly(vinyl alcohol)/poly(vinyl acetate) electrospun nanofibrous mats as a novel wound dressing matrix for controlled release of drugs, Int. J. Nanomed., 6 (2011) 993-1003.

20. K.H. Hong, J.L. Park, I.H. Sul, J.H. Youk, T.J. Kang, Preparation of antimicrobial poly (vinyl alcohol) nanofibers containing silver nanoparticles, J. Polym. Sci. Pol. Phys., 44 (2006) 2468-2474.

21. H.W. Lee, M.R. Karim, H.M. Ji, Electrospinning fabrication and characterization of poly (vinyl alcohol)/montmorillonite nanofiber mats, J. Appl. Polym. Sci., 113 (2009) 1860-1867.

22. K.E. Strawhecker, E. Manias, Structure and properties of poly(vinyl alcohol)/Na montmorillonite nanocomposites, Chem. Mater., 12 (2000) 2943-2949.
23. I.M. El-Sharbiny, S. Yahia, M.A. Messiery, M.F. Reichac, Preparation and physicochemical characterization of new nanocomposites based on -type chitosan and nano-hydroxyapatite as potential bone substitute materials, Int. J Polym. Mater. Po., 63 (2014) 213-220.

24. L. Lin, W. Z. Gong, S. Y. Wanga, Hollow PET fibers containing silver particles as antibacterial materials, J. Text. I., 102 (2011) 419-423.

25. S.T.C. Lin, D. Bhattacharyya, S. Fakirov, J. Cornish, Novel organic solvent free micro-/nano-fibrillar, nanoporous scaffolds for tissue engineering, Int. J Polym. Mater. Po., 63 (2014) 416-423.

26. J.C. Meredith, E.J. Amis, Lcst phase separation in biodegradable polymer blends: Poly(d,l-lactide) and poly(epsilon-caprolactone), Macromol. Chem. Phys., 201 (2000) 733-739.

27. M.A. Attawia, K.M. Herbert, C.T. Laurencin, Osteoblast-like cell adherance and migration through 3-dimensional porous polymer matrices, Biochem. Bioph. Res. Co., 213 (1995) 639-644.

28. Z.M.O. Rzayev, K. Salimi, Ö.Eğri, E. Pişkin, Functional copolymer/organo-MMT nanoarchitectures. XIX. Nanofabrication and characterization of poly(MA-alt1-octadecene)-g-PLA layered silicate nanocomposites with nanoporous core-shell morphology, Polym. Advan. Technol., 25 (2014), 294-306.

29. Z.M.O. Rzayev, D. Erdönmez, K. Erkan, M.Şimşek, U. Bunyatova, Functional Copolymer/OrganoMMT Nanoarchitectures. XXII. Fabrication and Characterization of Antifungal and Antibacterial Poly (Vinyl Alcohol-co-Vinyl Acetate/ODA-MMT/ AgNPs Nanofibers and Nanocoatings by eSpinning and c-Spinning Methods, Int. J. Polym. Mater. PO., 64 (2015), 267-278.

30. P.R. Rudolf, B.G Landes, Two-dimensional X-Ray diffraction and scattering of microcrystalline and polymeric materials, Spectroscopy, 9 (1994) 22-33.

31. Z.M.O. Rzayev, B. Şenol, B.E. Denkbaş, Functional copolymer/organo-montmorillonite nanoarchitectures. IX. Synthesis and nanostructuremorphology-thermal behaviour relationships of poly [(maleic anhydride)-alt-(acrylic acid)]/organomontmorillonite nanocomposites, Polym. Int., 60 (2011) 1446-1454. 